\title{
PENGUATAN KAPASITAS SUMBERDAYA REMAJA SEBAGAI UPAYA MEMINIMALISIR PERNIKAHAN DINI DI DESA NYEROT KECAMATAN JONGGAT KABUPATEN LOMBOK TENGAH
}

\author{
Tuti Harwati \\ Dosen Syari'ah \& Ekonomi Islam, UIN Mataram \\ tuti_harwati@yahoo.com
}

\begin{abstract}
Abstrak: Untuk itu, maka tujuan dari pengabdian masyarakat ini adalah Meningkatkan kapasitas Remaja dengan memberikan pengetahuan tentang konsep perkawinan dalam fiqih dan perundang-undangan Indonesia; memberikan pengetahuan tentang dampak pernikahan dini, dan memberikan pengetahuan tentang kesehatan reproduksi remaja, Remaja memiliki lifeskill sehingga dapat menunda usia perkawinan karena memiliki kesibukan dalam kehidupan sehari-hari, Berkurangnya angka pernikahan dini di desa Nyerot.

Metode atau Strategi yang digunakan untuk tercapainya kondisi yang diharapkan adalah Analisis awal dan pendataan terhadap remaja yang akan dilibatkan dalam kegiatan ini, Tahap persiapan yang terdiri dari mengundang nara sumber dari akademisi dan expert yang menyampaikan materi, Melakukan capacity building dalam bentuk penyampaian materi tentang perkawinan dalam fiqih dan perundangundangan Indonesia; dampak pernikahan dini dan kesehatan reproduksi, Penguatan sumberdaya remaja melalui pelatihan life skill, Evaluasi. Dalam tahapan ini akan dilakukan evaluasi terhadap proses capacity building yang sudah dilakukan. Dalam evaluasi ini juga akan dilakukan monitoring terhadap keberlanjutan atas telah dilakukannya pelatihan lifeskill terhadap remaja yang ikut dalam kegiatan ini, juga untuk melihat efektifitas dan efisiensi sistem kerja dan metode-metode yang telah digunakan dalam melakukan pemberdayaan ini.
\end{abstract}

Kata Kunci: Penguatan, Kapasitas Sumberdaya Remaja, Meminimalisir, Pernikahan Dini

\section{PENDAHULUAN}

Pernikahan dini adalah sebuah bentuk pernikahan yang salah satu atau kedua pasangan berusia di bawah 18 tahun. Dalam UU perkawinan nomor 1 tahun 1974 dijelaskan bahwa batas minimal usia menikah bagi perempuan 16 tahun dan lelaki 19 tahun. Pernikahan dini sering terjadi pada anak yang sedang mengikuti pendidikan atau pada mereka yang putus sekolah. Hal ini merupakan masalah sosial yang terjadi di masyarakat yang penyebab dan damapaknya amat kompleks mencakup social-budaya, ekonomi, pendidikan, kesehatan maupun psikis.

Badan Kependudukan dan Keluarga Berencana Nasional (BKKBN) Nusa Tenggara Barat (NTB) mencatat Kabupaten Lombok Tengah (termasuk di dalamnya Desa Nyerot) dan Lombok Timur menjadi daerah darurat pernikahan dini. Hal ini karena angka pernikahan usia di bawah umur relatif tinggi 
dibandingkan daerah lainnya sehingga dua kabupaten itu masuk zona darurat atau dalam isitilah masuk kuadran dua yang kondisinya cukup berat dan butuh perhatian serius. Hal itu berdasarkan Survei Sosial Ekonomi Nasional (Susenas), Data Kependudukan Indonesia (SDKI) yang dilakukan Badan Pusat Statistik (BPS) tahun 2013.

Hal senada diungkapkan Kepala Badan Pemberdayaan Perempuan Perlindungan Anak dan Keluarga Berencana (BP3KB) Nusa Tenggara Barat, Wismaningsih Drajadiah, mengatakan jumlah pernikahan dini di NTB relatif masih tinggi. Dimana, rata-rata usia pernikahan dini dibawah umur 19 tahun. Menurutnya, berdasarkan data BPS pada 2013, jumlah pernikahan dini di NTB mencapai 51,8 persen dibawah usia 19 tahun, dari total jumlah pernikahan. Dimana, mayoritas pernikahan di bawah usia 15 tahun sekitar 20 persen.

Ada berbagai alasan yang menyebabkan terjadinya pernikahan dini, salah satunya adalah Faktor Ekonomi. Faktor ekonomi menyebabkan anak putus sekolah sehingga membawa kemungkinan yang sangat besar untuk terjadinya pernikahan dini, dan orang tua menikahkan anaknya pada pria/keluarga yang lebih mapan atau hanya untuk mengurangi biaya hidup sehari hari.

Jumlah Angka Pernikahan dini yang terdokumentasi di Kantor Desa Nyerot tidak ada. Hal ini bisa dimaklumi karena keberadaan pernikahan mereka tidak tercatat sebab termasuk kategori pernikahan siri, kecuali yang mendapatkan dispensasi dari pihak Pengadilan Agama. Namun data tentang hal ini juga tidak ada.

Berdasarkan informasi dari Ibu Baiq Halwati (Mantan Ketua) Lembaga Swadaya Masyarakat Panca Karsa Mataram yang intens melakukan pemberdayaan terhadap masyarakat Desa Nyerot Kecamatan Jonggat Kabupaten Lombok Tengah menyampaikan kepada saya saat melakukan lifeskill bagi ibu-ibu mantan TKW di Desa Nyerot bahwa angka pernikahan dini di Desa Nyerot cukup tinggi sehingga banyak dari mereka yang kemudian pergi bekerja menjadi Tenaga Kerja Wanita ke luar negeri.

Beliau mengusulkan untuk meminimalisir praktik pernikahan dini, perlu dilakukan penguatan kapasitas berupa pemberian pengetahuan tentang 
Transformasi, Vol. 13, No. 1, Januari 2017: 80 - 91

pernikahan yang ideal dan pengetahuan tentang kesehatan reproduksi. Di samping itu, anak-anak yang putus sekolah yang memang lebih banyak yang menikah dini perlu diberikan lifeskill yang bisa memberikan kesibukan dalam kehidupan sehari-hari mereka, sehingga dapat mengulur usia perkawinannya.

Berdasarkan hal ini maka sangat urgent untuk dilakukan pengabdian masyarakat dengan tema "Penguatan Kapasitas Sumberdaya Remaja sebagai Upaya Meminimalisir Pernikahan Dini di Desa Nyerot Kecamatan Jonggat Kabupaten Lombok Tengah"

\section{PEMBAHASAN}

Milen mendefenisikan kapasitas sebagai kemampuan individu, organisasi atau sistem untuk menjalankan fungsi sebagaimana mestinya secara efektif, efisien dan terus-menerus. Sedangkan Morgan merumuskan pengertian kapasitas sebagai kemampuan, keterampilan, pemahaman, sikap, nilai-nilai, hubungan, perilaku, motivasi, sumber daya, dan kondisi-kondisi yang memungkinkan setiap individu, organisasi, jaringan kerja/ sektor, dan sistem yang lebih luas untuk melaksanakan fungsi-fungsi mereka dan mencapai tujuan pembangunan yang telah ditetapkan dari waktu ke waktu. Lebih lanjut, Milen melihat capacity building sebagai tugas khusus, karena tugas khusus tersebut berhubungan dengan faktorfaktor dalam suatu organisasi atau sistem tertentu pada suatu waktu tertentu. ${ }^{32}$

Masih dalam Milen, UNDP (United Nations Development Program) dan CIDA (Canadian International Development Agency) dalam Milen memberikan pengertian penguatan kapasitas sebagai: proses dimana individu, kelompok, organisasi, institusi, dan masyarakat meningkatkan kemampuan mereka untuk (a) menghasilkan kinerja pelaksanaan tugas pokok dan fungsi (core functions), memecahkan permasalahan, merumuskan dan mewujudkan pencapaian tujuan yang telah ditetapkan, dan (b) memahami dan memenuhi kebutuhan pembangunan dalam konteks yang lebih luas dalam cara yang berkelanjutan. ${ }^{33}$

32 Anni Milen, Pegangan Dasar Pengembangan Kapasitas, (Yogyakarta: Pondok Pustaka Jogja, 2004), h. 12.

${ }^{33}$ Ibid, h. 15. 
Adapun menurut Soeprapto, ${ }^{34}$ Pengembangan kapasitas pada umumnya diartikan sebagai peningkatan kemampuan atau kompetensi individu, kelompok dan organisasi yang mencangkup banyak komponen, sehingga didalam pengembangan kapasitas terdapat beberapa dimensi dan fokus. Dimensi dan focus tersebut merupakan bagian proses dinamis yang berkelanjutan.

Tujuan dari Capacity Building (penguatan kapasitas) dapat dibagi menjadi 2 bagian yaitu :

a. Secara umum diidentikkan pada perwujudan sustainabilitas (keberlanjutan) suatu sistem.

b. Secara khusus ditujukan untuk mewujudkan kinerja yang lebih baik dilihat dari aspek :

1) Efisiensi dalam hal waktu (time) dan sumber daya (resources) yang dibutuhkan guna mencapai suatu outcome

2) Efektifitas berupa kepantasan usaha yang dilakukan demi hasil yang diinginkan

3) Responsifitas yakni bagaimana mensinkronkan antara kebutuhan dan kemampuan untuk maksud tersebut.

4) Pembelajaran yang terindikasi pada kinerja individu, grup, organisasi dan sistem. ${ }^{35}$

Karakteristik Penguatan kapasitas/ Capacity Building

Ciri-ciri atau karakteristik Penguatan kapasitas/Capacity Building dicirikan dengan hal-hal sebagai berikut: ${ }^{36}$ Merupakan sebuah proses yang berkelanjutan, Memiliki esesensi sebagai sebuah proses internal, Dibangun dari potensi yang telah ada, Memiliki nilai intrinsik tersendiri, Mengurus masalah perubahan, Menggunakan pendekatan terintegrasi dan holistik.

Dimensi dan Tingkatan Penguatan kapasitas/Capacity Building. Faktorfaktor yang mempengaruhi Penguatan kapasitas/ Capacity Building

${ }^{34}$ Soeprapto, Pengembangan Kapasitas Pemerintah Daerah Menuju Good Government, (Malang: Fakultas Ilmu Administrasi Universitas Brawijaya, 2003), h.14.

${ }^{35}$ Yeremias. T. Keban. "Good Governance" dan "Capacity Building" sebagai Indikator Utama dan Fokus Penilaian, (Jakarta: Jurnal Perencanaan Pembangunan, 2000), h. 7

${ }^{36}$ Rida Gandara, Capacity Building Dosen pada Jurusan di Perguruan Tinggi Badan Hukum Miliki Negara, (Bandung: Fakultas Ilmu Pendidikan UPI, 2008), h. 16. 
Transformasi, Vol. 13, No. 1, Januari 2017: 80 - 91

Terdapat banyak faktor yang mempengaruhi penyelenggaraan maupun kesuksesan program pengembangan kapasitas. Namun secara khusus Soeprapto mengemukakan bahwa faktor-faktor signifikan yang mempengaruhi pengembangan kapasitas adalah sebagai berikut: ${ }^{37}$

a. Komitmen bersama.

Collective commitments dari seluruh aktor yang terlibat dalam sebuah organisasi sangat menentukan sejauh mana pengembangan kapasitas akan dilaksanakan ataupun disukseskan. Komitmen bersama ini merupakan modal dasar yang harus terus menerus ditumbuhkembangkan dan dipelihara secara baik oleh karena faktor ini akan menjadi dasar dari seluruh rancangan kegiatan yang akan dilakukan oleh sebuah organisasi. Tanpa adanya komitmen baik dari pimpinan tingkat atas, menengah maupun bawah dan juga staff yang dimiliki, sangatlah mustahil mengharapkan program pengembangan kapasitas bisa berlangsung apalagi berhasil dengan baik.

b. Kepemimpinan.

Faktor conducive leadership merupakan salah satu hal yang paling mendasar dalam mempengaruhi inisiasi dan kesuksesan program pengembangan kapasitas personal dalam kelembagaan sebuah organisasi. Dalam konteks lingkungan organisasi publik, harus terus menerus didorong sebuah mekanisme kepemimpinan yang dinamis sebagaimana yang dilakukan oleh sektor swasta. Hal ini karena tantangan ke depan yang semakin berat dan juga realitas keterbatasan sumber daya yang dimiliki sektor publik. Kepemimpinan kondusif yang memberikan kesempatan luas pada setiap elemen organisasi dalam menyelenggarakan pengembangan kapasitas merupakan sebuah modal dasar dalam menentukan efektivitas kapasitas kelembagaan menuju realisasi tujuan organisasi yang diinginkan.

37 Soeprapto Riyadi, "Pengembangan Kapasitas Pemerintah Daerah Menuju Good Governance", Jurnal IImiah Administrasi Publik, (Malang: FIA UNIBRAW, 2006), h. 20. 
c. Reformasi peraturan.

Kontekstualitas politik pemerintahan daerah di indonesia serta budaya pegawai pemerintah daerah yang selalu berlindung pada peraturan yang ada serta lain-lain faktor legal-formalprosedural merupakan hambatan yang paling serius dalam kesuksesan program pengembangan kapasitas. Oleh karena itulah, sebagai sebuah bagian dari implementasi program yang sangat dipengaruhi oleh faktor kepemimpinan maka reformasi (atau dapat dibaca penyelenggaran peraturan yang kondusif) merupakan salah satu cara yang perlu dilakukan dalam rangka menyukseskan program kapasitas ini.

d. Reformasi kelembagaan.

Reformasi peraturan di atas tentunya merupakan salah satu bagian penting dari reformasi kelembagaan ini. Reformasi kelembagaan pada intinya menunjuk kepada pengembangan iklim dan budaya yang kondusif bagi penyelenggaraan program kapasitas personal dan kelembagaan menuju pada realisasi tujuan yang ingin dicapai. Reformasi kelembagaan menunjuk dua aspek penting yaitu struktural dan kultural. Kedua aspek ini harus dikelola sedemikian rupa dan menjadi aspek yang penting dan kondusif dalam menopang program.

Pengembangan kapasitas harus diawali pada identifikasi kapasitas yang dimiliki maka harus ada pengakuan dari personal dan lembaga tentang kelemahan dan kekuatan yang dimiliki dari kapasitas yang tersedia (existing capacities). Pengakuan ini penting karena kejujuran tentang kemampuan yang dimiliki merupakan setengah syarat yang harus dimiliki dalam rangka menyukseskan program pengembangan kapasitas.

Pengembangan kapasitas memiliki cara tersendiri untuk menjalannya aktifitasnya yang memungkinkan terjadinya pengembangan kapasitas pada sebuah individu, sistem, atau organisasi, dimana pada aktifitas tersebut terdiri atas beberapa tahapan umum. Adapun tahapan atau fase tersebut adalah; Persiapan, analisis, perencanaan. Implementasi, evaluasi ${ }^{38}$

${ }^{38}$ Gandara, Capacity Building Dosen pada Jurusan di Perguruan Tinggi Hukum Milik Negara, (Bandung: UPI, 2008), h.18. 
Transformasi, Vol. 13, No. 1, Januari 2017: 80 - 91

\section{PROSES PELAKSANAAN KEGIATAN}

\section{Bentuk Kegiatan}

Bentuk kegiatan yang digunakan untuk tercapainya tujuan yang diharapkan dalam kegiatan penguatan kapasitas sumberdaya remaja ini dijelaskan dengan beberapa tahapan berikut:

1. Tahap persiapan

Pada tahap persiapan, kegiatan yang dilakukan adalah

a. Analisis awal dan pendataan terhadap jumlah dan kondisi remaja yang ada di Desa Nyerot Kecamatan Jonggat Kabupaten Lombok Tengah yang akan dilibatkan dalam kegiatan penguatan kapasitas sumberdaya remaja ini.

b. Menyiapkan Nara sumber yang membantu pengabdi di dalam memberikan materi yang terkait dengan:

1) Pernikahan menurut fiqih dan Hukum Perdata Islam Indonesia

2) Dampak pernikahan dini

3) peran perempuan kepala keluarga sebagai pencari nafkah utama dalam keluarga

4) Kesehatan reproduksi perempuan

2. Pembuatan stick singkong

Dalam tahapan ini metode yang dilakukan adalah mengumpulkan data awal tentang profil Desa Nyerot dan data tentang remaja putri yang dilibatkan dalam kegiatan pengabdian ini. Dari data awal ini kemudian pengabdi melakukan wawancara dengan beberapa stake holder yang ada di Desa Nyerot. Data awal dan hasil wawancara kemudian dianalisis untuk mendapatkan gambaran yang komprehensif tentang keberadaan remaja putri. Hasil analisis inilah yang menjadi pertimbangan bagi pengabdi untuk melakukan kegiatan penguatan kapasitas sumberdaya remaja ini.

3. Tahap Pengkajian

Pada tahap pengkajian ini, kegiatan yang dilakukan adalah

a. menganalisis sumberdaya yang dimiliki di Desa Nyerot. Hal ini dilakukan untuk memudahkan remaja yang dilibatkan dalam kegiatan ini untuk 
menentukan keterampilan yang akan didapatkan atau butuhkan sesuai dengan potensi lokal yang ada.

b. menganalisis potensi berkembangnya usaha stick singkong yang merupakan hasil keterampilan yang diperoleh dalam kegiatan pengauatan kapasitas ini.

Pada tahapan ini metode yang digunakan adalah bertemu langsung dengan para remaja yang dilibatkan dalam kegiatan ini. Dalam pertemuan ini, pengabdi melakukan diskusi langsung dan para remaja menyampaikan sumberdaya yang mereka miliki dan potensi-potensi usaha kecil di Desa Nyerot.

4. Tahap Perencanaan Kegiatan

Pada tahapan ini, berdasarkan hasil analisis terhadap data awal yang sudah diperoleh dan berdasarkan hasil diskusi dengan stake holders dan remaja di Desa Nyerot, kemudian diputuskan untuk membuat program atau kegiatan dalam bentuk penguatan kapasitas dengan rumusan kegiatan "Penguatan Kapasitas Sumberdaya Remaja sebagai Upaya Meminimalisir Pernikahan Dini di Desa Nyerot Kec. Jonggat Kab. Lombok Tengah".

Metode yang digunakan dalam kegiatan ini adalah pengabdi selain melibatkan para remaja juga melibatkan stake holders sebanyak 10 orang. Para stake holders ini memberikan sumbangan pemikiran tentang kegiatan atau program yang dibutuhkan oleh pera remaja di Desa Nyerot.

5. Tahap Capacity Building

Kegiatan yang dilakukan pada tahap ini adalah memberikan pengetahuan dan pelatihan kepada remaja Desa Nyerot untuk penguatan kapasitasnya. Kegiatan ini dilaksanakan enam belas jam jam.

Metode yang dipakai dalam dalam tahapan ini adalah pada hari pertama sebelum penguatan kapasitas sumberdaya remaja dimulai, pengabdi terlebih dahulu menyampaikan kepada remaja tentang signifikansi dan tujuan diadakannya kegiatan pengauatan kapasitas ini. Setelah pembukaan, kemudian dilanjutkan dengan sesi materi yang disampaikan oleh nara sumber terkait dengan: 
Transformasi, Vol. 13, No. 1, Januari 2017: 80 - 91
a. Pernikahan menurut fiqih dan hokum perdata Islam Indonesia
b. Dampak pernikahan dini
c. Kesehatan Reproduksi perempuan

Pada hari kedua kemudian dilanjutkan dengan sesi pelatihan pembuatan stick singkong. Selama kegiatan dalam tahapan ini, pengabdi dibantu oleh para stake holders sebanyak 10 orang.

6. Tahap Pelaksanaan

Kegiatan yang dilakukan pada tahap ini adalah pengabdi menghadirkan nara sumber yang menyampaikan materi tentang pernikahan dini dan expert yang memandu cara pembuatan stick singkong. Metode yang digunakan dalam kegiatan ini adalah pengabdi dan remaja yang dilibatkan dalam kegiatan inia berkumpul di aula Kantor Desa Nyerot. Di tempat inilah nara sumber yang didampingi pengabdi memberikan materi dan keterampilan pembuatan stick singkong.

7. Tahap Evaluasi

Kegiatan yang dilakukan dalam tahapan ini adalah pengabdi memastikan bahwa para remaja yang terlibat dalam kegiatan ini bisa membuat sendiri stick singkong sebagaimana yang telah diajarkan dalam kegiatan pengabdian ini. Metode yang dipakai adalah pengabdi melakukan monitoring selama dua kali setelah kegiatan pengabdian dilakukan.

\section{Kendala yang Dihadapi dan Upaya Pemecahannya}

Selama pelaksanaan kegiatan pengabdian ini, tentu terdapat beberapa kendala yang dihadapi, baik dari tahap persiapan maupun samapai pada tahap terakhir yakni tahap terminasi. Kendala-kendala tersebut antara lain:

1. Pada tahap persiapan pengabdi mengalami sedikit kesulitan dalam mendapatkan data Desa Nyerot yang berisi tentang keberadaan remaja sebagai subyek sasaran kegiatan pengabdian. Kemudian hal ini pengabdi atasi dengan mencari informasi dari aktivis perempuan yang aktif melakukan pengabdian di Desa Nyerot. 
2. Pada tahap pelaksanaan kegiatan dana pengabdian dari IAIN mataram belum cair seluruhnya sehingga jadwal kegiatan mundur dari rencana semula. Kondisi ini pengabdi atasi dengan meminjamkan dana talangan.

3. Pada tahap monitoring, lokasi masing-masing tempat tinggal peserta jauh. Kondisi ini pengabdi atasi dengan menggunakan driver.

\section{Kegiatan Penilaian yang Digunakan untuk Melihat Keberhasilan}

Ada dua kegiatan yang dilakukan untuk melihat keberhasilan pelaksanaan kegiatan pengauatan kapasitas sumberdaya remaja, Yaitu Monitoring dan evaluasi.

Pertama, Monitoring

Diantara tujuan monitoring adalah:

1. Kegiatan monitoring bertujuan untuk memantau suatu kegiatan pemberdyaan dan pengembangan dalam pencapaian sasaran. Kegiatan monitoring meliputi mekanisme monitoring, fokus monitoring, acuan monitoring, jadwal monitoring.

2. Monitoring adalah pengumpulan dan analisis informasi secara sistematis untuk melihat kemajuan dari suatu pemberdayaan

3. Monitoring bertujuan untuk meningkatkan efisiensi dan efektifitas dari sebuah project atau organisasi.

4. Monitoring berdasarkan target dan kegiatan yang telah direncanakan selama proses pekerjaaan berlangsung.

Pelaksanaan monitoring dapat dilakukan dengan berbagai cara, disesuaikan dengan situasi dan kondisi yang ada. Untuk monitoring dalam kegiatan pemberdayaan ini dilakukan dengan cara diskusi langsung secara bersama remaja yang terlibat dalam kegiatan ini.

Kedua, Evaluasi

Evaluasi merupakan rangkuman hasil pengukuran capaian pemberdayaan, yang berkontribusi terhadap capaian outcome yang ditetapkan dalam Term of Reference kegiatan pengabdian. Evaluasi adalah perbandingan dari actual project dengan perencanaan strategi yang telah disepakati 
Transformasi, Vol. 13, No. 1, Januari 2017: 80 - 91

Evaluasi mencakup:

1. Apa perbedaan yang ingin dibuat? Apa dampak yang ingin dihasilkan?

2. Mengkaji kemajuan pemberdayaan yang ingin didapatkan sebagai target/dampak.

3. Untuk melihat seberapa efektif strategi tersebut?

Dalam kegiatan monitoring dan evaluasi ini dilakukan pengumpulan informasi melalui:

1. Observasi

2. Mencatat and menganalisa peristiwa penting (disebut 'Analisis kejadian penting")

3. Interview/ wawancara satu per satu

4. Diskusi kelompok

\section{KESIMPULAN}

Dari paparan di atas dapat disimpulkan beberapa hal:

1. Sebelum dilaksanakannya kegiatan pengabdian, kondisi remaja putri yang menjadi sasaran pengabdian di Desa Nyerot Kecamatan Jonggat Kabupaten Lombok Tengah adalah belum memiliki pengetahuan yang memadai tentang:

a. pernikahan secara fiqih maupun secara hukum perdata islam Indonesia;

b. dampak pernikahan dini;

c. kesehatan reproduksi remaja;

d. pembuatan stick singkong;

Namun setelah dilakukan kegiatan penguatan kapasitas/capacity building mereka memiliki pengetahuan tentang pernikahan secara fiqih maupun secara hukum perdata islam Indonesia; dampak pernikahan dini; kesehatan reproduksi remaja; dan mampu membuat stick singkong sebagai keterampilan mereka.

2. Strategi/metode yang dipakai dalam kegiatan penguatan kapasitas ini untuk hari pertama sebelum pelatihan dimulai, pengabdi terlebih dahulu menyampaikan kepada remaja tentang signifikansi dan tujuan diadakannya kegiatan penguatan kapasitas ini.

Setelah pembukaan, kemudian dilanjutkan dengan sesi materi yang disampaikan oleh nara sumber. Dilanjutkan pada hari kedua yakni pelatihan keterampilan. 
Tuti Harwati, Penguatan Kapasitas...

\section{DAFTAR PUSTAKA}

Anni Milen, Pegangan Dasar Pengembangan Kapasitas, Yogyakarta: Pondok Pustaka Jogja, 2004.

Gandara, Capacity Building Dosen pada Jurusan di Perguruan Tinggi Hukum Milik Negara, Bandung: UPI, 2008.

Imam Hardjanto, Pembangunan Kapasitas Lokal (Local Capacity Building),Malang: Program Pascasarjana Universitas Brawijaya, 2006

Richard M, Steers, Efektivitas Organisasi, Erlangga, Jakarta: 1984.

Rida Gandara, Capacity Building Dosen pada Jurusan di Perguruan Tinggi Badan Hukum Miliki Negara, Bandung: Fakultas Ilmu Pendidikan UPI, 2008.

Soeprapto Riyadi, "Pengembangan Kapasitas Pemerintah Daerah Menuju Good Governance", Jurnal IImiah Administrasi Publik, Malang: FIA UNIBRAW, 2006.

Tim Peneliti, Capacity Building Birokrasi Pemerintah Daerah Kabupaten/Kota Di Indonesia, Makassar: STIA LAN, 2012.

Yeremias. T. Keban. "Good Governance" dan "Capacity Building" sebagai Indikator Utama dan Fokus Penilaian, Jakarta: Jurnal Perencanaan Pembangunan, 2000. 